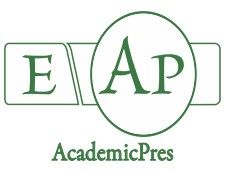

Michel-Cuello C et al. (2021)

Notulae Botanicae Horti Agrobotanici Cluj-Napoca

Volume 49, Issue 1, Article number 12154

DOI:10.15835/nbha49112154

Research Article

\title{
Fermentable carbohydrate metabolism in maguey mezcalero potosino (Agave salmiana): HPLC characterization and evaluation
}

\author{
Christian MICHEL-CUELLO ${ }^{1 *}$, Noé AGUILAR-RIVERA², \\ Cristian LÓPEZ-PALACIOS ${ }^{1}$, Juan F. CÁRDENAS-GONZÁLEZ ${ }^{1}$ \\ ${ }^{1}$ Autonomous University of San Luis Potosí, Middle Zone Multidisciplinary Academic Unit, Rioverde-San Ciro Highway, Km 4 \\ Ejido Puente del Carmen, 79617, Rioverde, San Luis Potosí, México; christian.michel@uaslp.mx ("corresponding author); \\ cristian.lopez@uaslp.mx; juan.cardenas@uaslp.mx \\ ${ }^{2}$ University of Veracruz, Faculty of Biological and Agricultural Sciences, Orizaba Córdoba región, Camino Peñuela-Amatlán s/n \\ Peñuela, Amatlán de los Reyes,94952,Veracruz,México;naguilar@uv.mx
}

\begin{abstract}
The maguey mezcalero potosino (Agave salmiana) is a natural resource of great regional importance, used for the manufacture of mezcal and other alcoholic beverages by fermentation of simple sugars and sugars released by fructans hydrolysis. For this, only the stem and base of leaves is used, which results on wasting the other sections that represent up to $40 \%$ of weight of the complete plant. The objective of this study was to identify and quantify the fermentable carbohydrates present in raw and hydrolysed juices of the stem and four sections of the whole leaves (base, neck, wings and apex) of maguey plants with representative specimens of three stages of maturity with industrial importance. For carbohydrate characterization, high resolution liquid chromatography (HLPC) was used. The sugars found as fructose, glucose, sucrose, xylose and maltose coincide with those identified in other Agave species, significant differences are observed depending on the section and the state of maturity of the plant, the sugar concentration in the discarded sections of the plant (fructose: 5.79 - $4.80 \mathrm{mg} \mathrm{mL}^{-1}$ ) are considerable and statistically similar to those found in the stem (fructose: $2.49 \mathrm{mg} \mathrm{mL}^{-1}$ ) and the base of the leaf (fructose: $3.16 \mathrm{mg} \mathrm{mL}^{-1}$ ) (structure used in the mezcal production process). The results obtained can promote the integral use of the plant and diversification towards other industries such as pharmaceuticals, biofuels or foods.
\end{abstract}

Keywords: Agave, carbohydrate metabolism; San Luis Potosi; sugar identification and quantification

\section{Introduction}

The maguey mezcalero potosino (Agave salmiana) is a very abundant and widely distributed resource in the highlands of the states of San Luis Potosí and Zacatecas in Mexico. It is of great economic importance since its leaves are currently used as fodder for livestock, as a source of a traditional drink named mead or commonly called "aguamiel", obtained from scraping the inside of the stem and is mainly composed of processed sap (Romero et al., 2015) and with industrial use of the complete stem and the bases of the leaves or "pencas" for the production of mezcal (Lara et al., 2017; Gómez et al., 2019). The origin of the word mezcal or mexcal is the term "mexcalli", and it comes from the Nahuatl language in Mexico, its etymology is "metl": maguey and

Received: 11 Nov 2020. Received in revised form: 25 Jan 2021. Accepted: 03 Feb 2021. Published online: 08 Feb 2021.

From Volume 49, Issue 1, 2021, Notulae Botanicae Horti Agrobotanici Cluj-Napoca journal will use article numbers in place of the traditional method of continuous pagination through the volume. The journal will continue to appear quarterly, as before, with four annual numbers. 
"ixcalli": cooked or boiled; and is interpreted as an alcoholic drink obtained from the fermentation and distillation of honeys extracted from cooked maguey heads (Aguirre et al., 2001). Currently in the state of San Luis Potosí (SLP) five companies make mezcal, their processes vary from the artisan way to the industrial way, of which some are private property and others communal property.

Aguirre et al. (2001), points out that the maguey in the state of SLP, presents an optimal growth in environments located between 1,000 to 2,250 meters above sea level, climate from semi-dry (BS1) to dry (BS0), rainfall of 320 to $720 \mathrm{~mm}$ per year, thermal regime from temperate to extreme semi-warm and average annual temperature of $16{ }^{\circ} \mathrm{C}$ to $22^{\circ} \mathrm{C}$. The suitable geological substrate is igneous with variable soil development, mainly xerosols more than $0.30 \mathrm{~m}$ thick and moderate to high clay contents. The magueys present only one flowering and later the plant dies. Its physical structure stands out for its rosette shape, made up of a thick and short stem, in which the leaves are inserted, which depending on their maturity unfold from the central axis and the most senile ones are almost lying on the ground (Aguirre et al., 2001; García et al., 2010; Esparza et al., 2015). Taking as reference the historical exploitation of the maguey by the mezcal haciendas of the state of SLP, Aguirre et al. (2001) determined the optimal areas for the use of this natural resource and its geographical distribution (Figure 1). This area covers 17 municipalities and nearly $50 \%$ of the surface of the state. Currently, the maguey populations have been affected by the change in land use for new crops, over-exploitation to obtain forage and lack of cultural work such as plantation for repopulation of maguey.

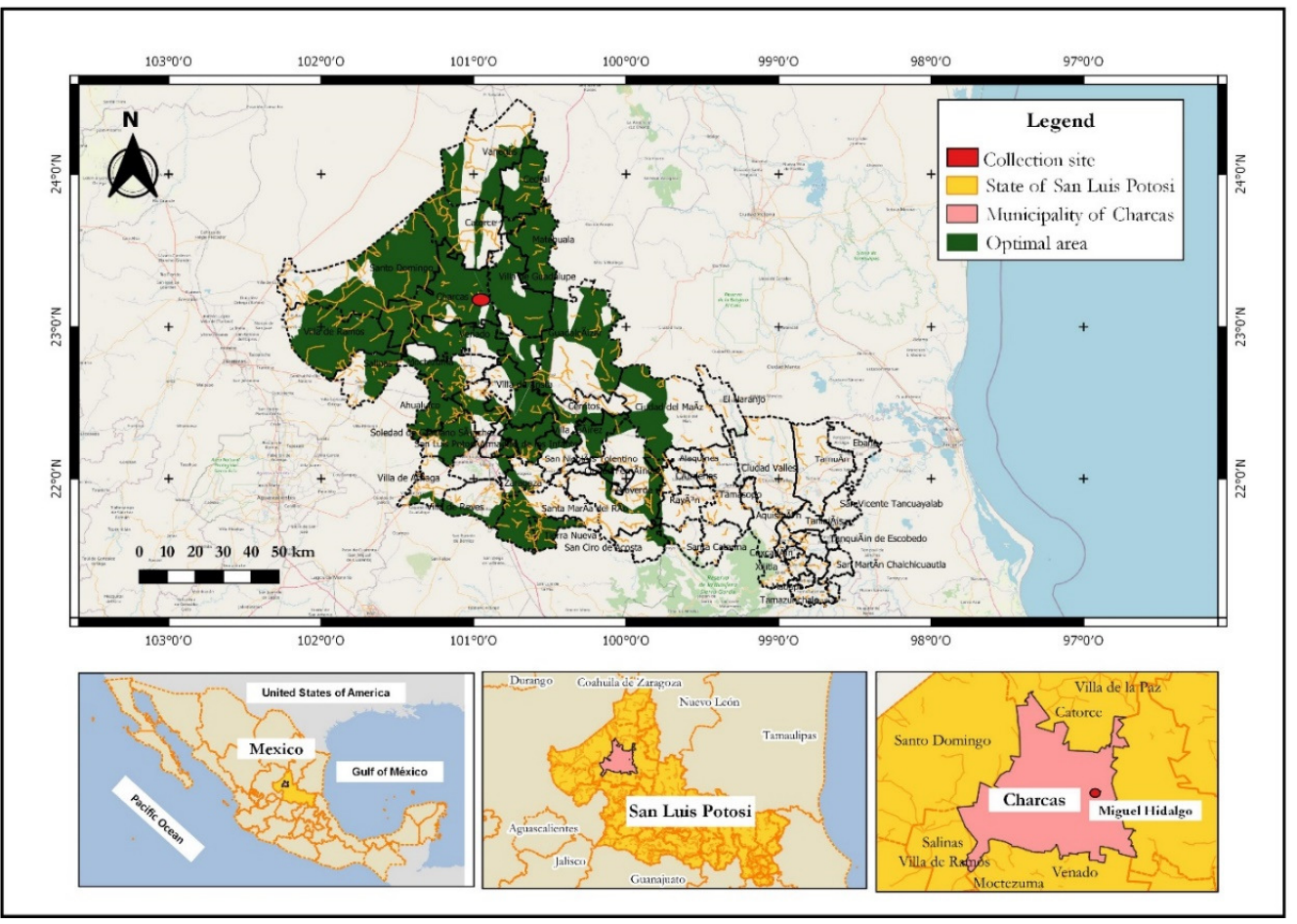

Figure 1. Geographic distribution of maguey mezcalero (Agave salmiana) in the state of San Luis Potosí, México (Data from Aguirre et al., 2001)

Plants of the genus Agave present a physiological adaptation known as Crassulaceae Acid Metabolism (CAM), in which carbon assimilation takes place at night, when the atmospheric demand for water is very low. In this way they can keep the stomata open with very little water loss and close the stomata during the day when the atmospheric demand is high. For this reason, CAM photosynthesis is associated with a high efficiency in the use of water (Goldstein et al., 1991; Zhang and Nobel, 1996; Zúñiga et al., 2018). 
Carbohydrates are formed during the photosynthesis process, where plants use energy from sunlight to transform carbon dioxide $\left(\mathrm{CO}_{2}\right)$ and water $\left(\mathrm{H}_{2} \mathrm{O}\right)$ in the atmosphere into simple sugars and release oxygen $\left(\mathrm{O}_{2}\right)$. Sugars are found in the plant in a dynamic state, where they are the energy potential source required by cellular reactions, such as protein synthesis, lipids, etc. Once the sugars are formed in the leaves, they must be transported to other organs (fruits, roots and storage areas). In the phloem fluid, sugars represent between $80 \%$ and $90 \%$ of the total dry matter, and among them, sucrose is the most abundant; some species carry other oligosaccharides such as raffinose, stachyose, and verbascose. Although two hexoses, glucose and fructose, are commonly found in the phloem of plants, they are not transported since they come from the hydrolysis of sucrose and its related sugars. In the maguey there is a mixture of fructooligosaccharides called fructans, which are synthesized from fructose and glucose and are stored in the stem as a reserve energy source (López et al., 2003; Ritsema and Smeekens, 2003; Acosta et al., 2018; García et al., 2020).

Chromatography is a method of separation, qualitative identification and quantitative determination of chemical compounds in complex mixtures. This method has been widely used in the identification of carbohydrates in plants and foods (Hofer and Jenewein, 1999), beverages (Lee and Coates, 2000; Chinnici et al., 2002), and sweeteners (Mora and Marioli, 2001). Studies carried out by Srinivasan and Bhatia (1953) in raw juices from the stem of Agave vera-cruz Mill. by ascending flat chromatography report the presence of fructose, glucose and sucrose. HPLC is recognized as a fast and accurate technique that allows determinations of multiple analytes in complex matrices and has been applied in recent years for reliable determinations in food and beverages (Jaramillo et al., 2020).

In mezcal factories, only the maguey heads also known as pineapples are used, a structure formed by the stem and the base of the leaves, the rest of the leaves are discarded due to the erroneous belief that they do not contain a considerable amount of sugars. The process of cutting the leaves (up to $40 \%$ of the weight of the complete plant) is carried out in the field at the time of the extraction of the maguey, the discarded leaves are used as subsistence forage for livestock. The waste of almost half the weight of the maguey plant exerts great pressure on the ecosystem where it is developed and used in a forest way.

The most important quality factor of the maguey plant used as raw material is the maturity state, since it determines the carbohydrates amount stored as a reserve. Because most of the maguey is wild, there is no direct relationship between size and maturity (Aguirre et al., 2001). In the mezcal production process in SLP, three maturity stages are empirically considered: 1) Immature or young plants, 2) Quiotilla plants, when the plant shows signs of the beginning of its reproductive stage as the apex or end of the leaves thinned at its base and recently expanded leaves with smaller size and shiny black spines, and 3) Castrated plants, a plant that was subjected to the removal of the apical meristem or bud. The castration process inhibits the plant from using its energy reserves during its reproduction period, evidenced by the formation of the floral scape and the seeds formation and dispersal, it also extends the optimal period for their collection and use (Aguirre et al., 2001). Through cooking in mezcal factories, fructans in agave heads are hydrolysed, thereby releasing fructose and glucose, along with other mono-and disaccharides probably present in juice, which afterward undergo fermentation to produce alcohol (Michel-Cuello et al., 2008; Solís et al., 2017). The carbohydrates amount present in maguey juices determine the quality of the products that are made with this plant, mainly alcoholic beverages and sweeteners.

The objective of this study was to identify and quantify the fermentable carbohydrates present in raw and hydrolysed juices of the stem and of the four sections of the leaf belonging to three stages of maturity by HPLC. This information will enrich the knowledge about the sugars fermentable metabolism of the maguey mezcalero potosino (Agave salmiana), applicable to improve the yields of mezcal production and diversification towards other industries such as pharmaceuticals or food. 


\section{Materials and Methods}

Raw materials

Complete plants of maguey mezcalero potosino were collected in the Laguna Seca Mezcal Factory supply area in the municipality of Charcas, San Luis Potosí, specifically in the Miguel Hidalgo locality, whose location is $23^{\circ} 13^{\prime} 47^{\prime \prime} \mathrm{N} ; 100^{\circ} 54^{\prime} 58^{\prime \prime} \mathrm{W}$ at 2,060 $\mathrm{m}$ above sea level (Figure 1). The plants were representative of the three maturity stages with industrial importance and classified as follows: 1) Immature plants, 2) Quiotilla plants and 3) Castrated plants. The plants were sectioned in stem and leaves, which were divided transversely in four easily differentiated sections namely base, neck, wings and apex. The juices from each of the maguey sections were obtained using a horizontal three-cylinder stainless-steel sugar cane mill RJ-50 from Gerrey (Bogota, Colombia). The fiber was removed with a Pentek cellulose filter medium ECP20-10, whit $5 \mu \mathrm{m}$ pore diameter (Wisconsin, USA). The juices were stored at $4{ }^{\circ} \mathrm{C}$ until their analysis (Michel-Cuello et al., 2008).

\section{Hydrolysis}

A study prior to this investigation, allowed to establish the best conditions for the thermal hydrolysis of maguey fructans. For it, 3 temperature levels were evaluated $\left(60,70\right.$ and $\left.80^{\circ} \mathrm{C}\right)$, samples were taken and analysed every $1 \mathrm{~h}$. The results of this kinetics determined that at $80{ }^{\circ} \mathrm{C}$ the highest fructose release rate was obtained without adverse effects and at $30 \mathrm{~h}$ the liberated fructose concentration remained constant without statistically significant changes (Michel-Cuello et al., 2008). Thus, $80^{\circ} \mathrm{C}$ and $30 \mathrm{~h}$ were established as optimal process conditions, which were also comparable with those used by mezcal factories $\left(120^{\circ} \mathrm{C}\right.$ for $\left.30 \mathrm{~h}\right)$ (MichelCuello, 2004) and tequila $\left(100^{\circ} \mathrm{C}\right.$ for $\left.32 \mathrm{~h}\right)$ (López and Mancilla, 2002).

\section{Chromatographic determination}

The identification and quantification of carbohydrates was adapted according to the HPLC method proposed by Michel-Cuello et al. (2008), under the following conditions.

\section{$\underline{\text { Reagents and standards }}$}

Water and Acetonitrile HPLC grade from JT-Baker (Deventer, The Netherlands), CAR-11 carbohydrate kit (arabinose, fructose, galactose, glucose, lactose, maltose, mannose, ribose, sucrose and xylose) from Sigma-Aldrich (Steinheim, Germany).

\section{Sample preparation}

The juice samples were diluted to $20 \%(\mathrm{v} / \mathrm{v})$, in a 50:50 (v/v) acetonitrile / water solution. As filtering medium, acrodisc filter with nylon membrane $(0.2 \mu \mathrm{m})$ coupled to $5 \mathrm{~mL}$ polypropylene syringes, both from Waters (Milford Ct, USA), was used, each analysis was performed immediately.

\section{HPLC Analysis}

Agilent HP 1100 series chromatographic equipment (Waldbronn, Germany) was used, consisting of a degasifier (G1379 A), quaternary pump (G1311 A), column compartment (G1316 A), refractive index detector (G1362 A). The samples were injected into the system with a $50 \mu \mathrm{L}$ (Lc 5182) syringe from Agilent (Sydney, Australia) and the manual injector was a $20 \mu \mathrm{L}$ Rheodyne (Cotati, Ca. USA). A Zorbax column specific for carbohydrates ( $4.6 \mathrm{~mm}$ internal diameter, $250 \mathrm{~mm}$ length, $5 \mu \mathrm{m}$ particle size) from Agilent (Palo Alto Ca. USA) was used as stationary phase (Michel-Cuello et al., 2008).

\section{Chromatographic conditions}

Chromatographic separations were achieved with a mobile phase with a 75:25 (v / v) ratio of acetonitrile-water with $1.4 \mathrm{~mL} \mathrm{~min}^{-1}$ flow. The injected sample volume was $20 \mu \mathrm{L}$. Each sample analysis time for chromatographic separation was $15 \mathrm{~min}$. The column compartment and detector temperature were kept at 
$30{ }^{\circ} \mathrm{C}$, and the laboratory temperature was kept constant at $20^{\circ} \mathrm{C}$. For the control of the system and the analysis of results, the HP Chem Station software for LC Rev A. 09. 03 from Agilent (Palo Alto Ca. USA) was used. All determinations were carried out in triplicate.

\section{Identification and quantification}

The compounds were identified by comparing their retention times with those of external standards and were quantified by the external standard method based on the area under the curve of each of the chromatogram peaks and ordered by the signal generated in the detector.

\section{Calibration}

Standard carbohydrate solutions (arabinose, fructose, galactose, glucose, lactose, maltose, mannose, ribose, sucrose and xylose) were used for the calibration curve. Due to the wide range of concentrations, two calibration curves were established, in the juices quantification the following levels were applied: 2, 4, 6, 8, 10, $20,40,60,80$ and $100 \mathrm{mg} \mathrm{mL}^{-1} . r$ values ranged between 0.9980 and $0.9999(p<0.05)$ and were determined to know the detector response uniformity over the concentration range. A mixture of standards was injected daily to identify variations in calibration.

\section{Experimental design and statistical analysis}

A completely randomized design with factorial arrangement of treatments $(3 \times 5 \times 2)$ was established. The factors and levels were: a) state of maturity: immature plants, quiotilla plants and castrated plants; b) part of the plant: stem, base, neck, wings and apex; c) treatment: raw juices and hydrolysed juices. The values of the carbohydrate concentrations were subjected to an analysis of variance (ANOVA) to detect differences in the means of the treatments (SAS, version 9, SAS, Inc., Cary, Nc, USA). When the effects were statistically significant, mean comparisons were made with the LSMEANS procedure.

\section{Results}

\section{Sugars identification and quantification}

In Figure 2, the chromatogram of the mixture of pure carbohydrates separated by the Zorbax HPLC column and detected by its refractive index is presented. All carbohydrate standards could be separated in a single run and the standard deviation in retention times ( $t R)$ was in all cases less than $\pm 0.15 \mathrm{~min}$.

Of the 10 standards used for the identification of sugars present in raw and hydrolysed maguey juices, only xylose, fructose, glucose, sucrose and maltose could be identified and quantified; the remainder were not considered because they were not present or their trace concentrations were lower than the detection limit.

The analysis of variance was performed for all identified and quantified carbohydrates, their $F$ values are presented in Table 1.

\section{Sugars concentration in raw and hydrolysed juices}

Fructose. The fructose concentration in maguey juices as a function of maturity state, plant section and treatment are shown in Figure 3. Thermal hydrolysis achieved a statistically significant increase in this sugar concentration within each section plant in the 3 maturity stages, evidence of this is the highest concentrations of all the treatments in the hydrolysed plants; especially in the stem that rose from 2.94 to $68.68 \mathrm{mg} \mathrm{mL}^{-1}$, and in the case of the leaf neck it was from 2.48 to $44.27 \mathrm{mg} \mathrm{mL}^{-1}$.

Glucose. The results of the glucose analysis are found in Figure 4. In the case of raw leaf base juices, a statistically significant difference is observed between juices from immature plants and quiotilla plants. In raw juice samples, the highest glucose concentration was observed in those from the immature plants stem with 
$12.22 \mathrm{mg} \mathrm{ml}^{-1}$, which when hydrolysed reached $14.42 \mathrm{mg} \mathrm{ml}^{-1}$. However, the highest sugar concentration was obtained when hydrolysing juices from the leaf neck of quiotilla plants that went from 7.96 to $16.25 \mathrm{mg} \mathrm{ml}^{-1}$.

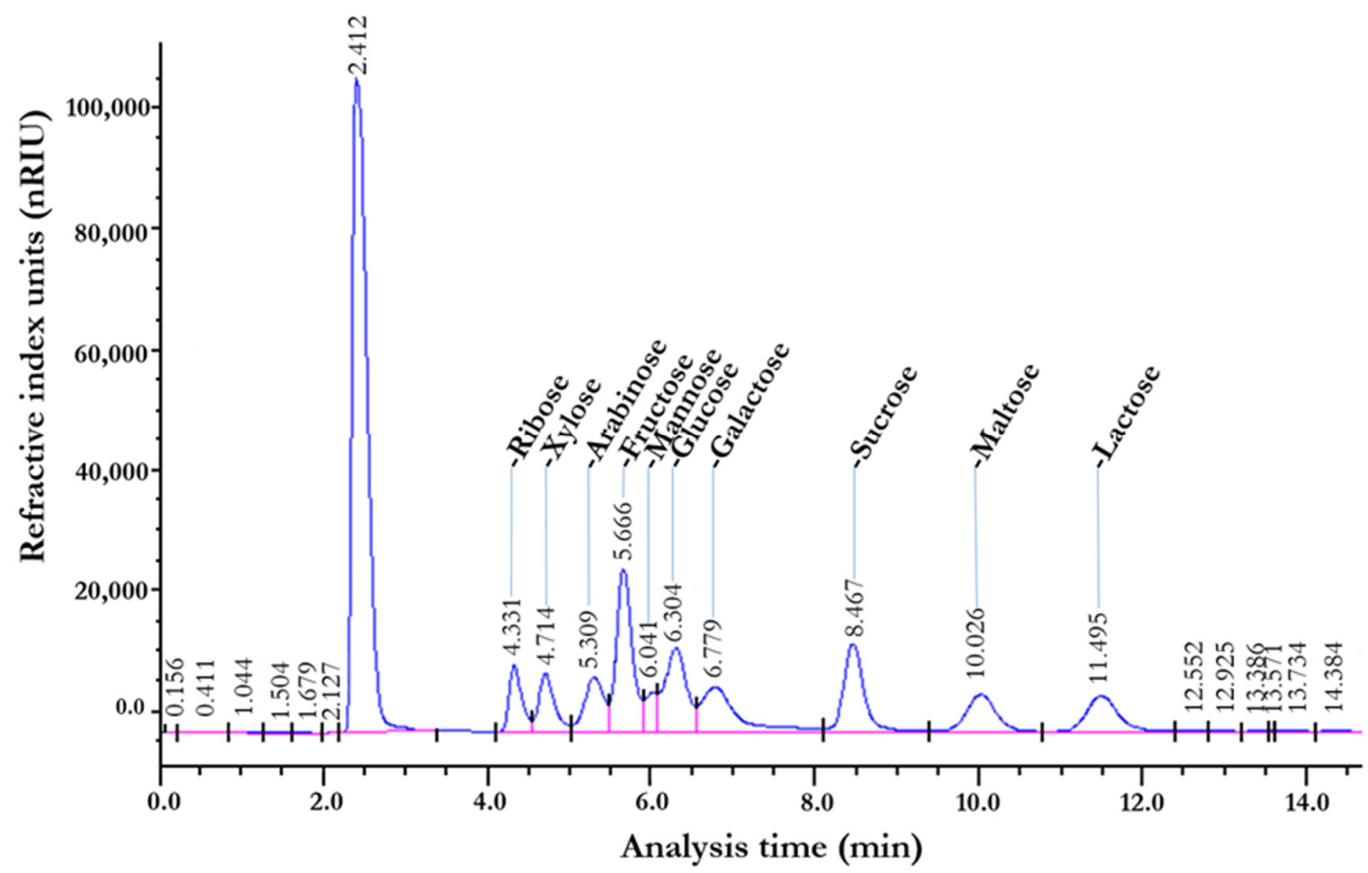

Figure 2. Retention times of a mixture of 10 standards used for the carbohydrate's identification in maguey juices (Agave salmiana)

The concentration of each standard was $5 \%(\mathrm{w} / \mathrm{v})$ in a 50:50 (v/v) acetonitrile / water solution (injection volume $20 \mu \mathrm{L})$.

Table 1. F test values of the concentration of sugars in maguey juice. Results of factorial arrangement of treatments $(3 \times 5 \times 2)$. The factors and levels were: a) state of maturity: immature plants, quiotilla plants and castrated plants; b) part of the plant: stem, base, neck, wings and apex; c) treatment: raw juices and hydrolysed juices

\begin{tabular}{|c|c|c|c|c|c|c|c|c|c|c|c|}
\hline \multirow{2}{*}{ Source } & & \multicolumn{2}{|c|}{ Fructose } & \multicolumn{2}{c|}{ Glucose } & \multicolumn{2}{c|}{ Sucrose } & \multicolumn{3}{c|}{ Xylose } & \multicolumn{2}{c|}{ Maltose } \\
\cline { 2 - 14 } & $D F$ & $F$ & $p$ & $F$ & $p$ & $F$ & $p$ & $F$ & $p$ & $F$ & $p$ \\
\hline Plant section & 4 & 4.52 & 0.003 & 0.72 & 0.579 & 2.02 & 0.104 & 7.78 & $<0.0001$ & 2.27 & 0.073 \\
\hline Maturity & 2 & 2.61 & 0.082 & 1.08 & 0.347 & 2.81 & 0.068 & 2.86 & 0.065 & 1.91 & 0.157 \\
\hline Treatment & 1 & 96.78 & $<0.0001$ & 9.32 & 0.003 & 5.25 & 0.026 & 11.13 & 0.002 & 5.24 & 0.026 \\
\hline Plant section * Maturity & 8 & 0.75 & 0.648 & 2.08 & 0.052 & 0.38 & 0.925 & 1.01 & 0.436 & 1.55 & 0.158 \\
\hline Plant section * Treatment & 4 & 5.16 & 0.001 & 1.80 & 0.140 & 3.13 & 0.021 & 1.33 & 0.268 & 4.59 & 0.003 \\
\hline Maturity Treatment & 2 & 5.67 & 0.006 & 5.89 & 0.005 & 0.93 & 0.400 & 4.90 & 0.011 & 0.89 & 0.418 \\
\hline Section ${ }^{*}$ Maturity * Treatment & 8 & 0.75 & 0.647 & 0.94 & 0.489 & 1.00 & 0.449 & 1.26 & 0.283 & 0.91 & 0.514 \\
\hline Model & 29 & 5.66 & $<0.0001$ & 1.98 & 0.013 & 1.53 & 0.083 & 2.80 & 0.000 & 2.00 & 0.012 \\
\hline Error & 60 & & & & & & & & & & \\
\hline Total (corrected) & 89 & & & & & & & & & & \\
\hline
\end{tabular}




\section{Fructose}

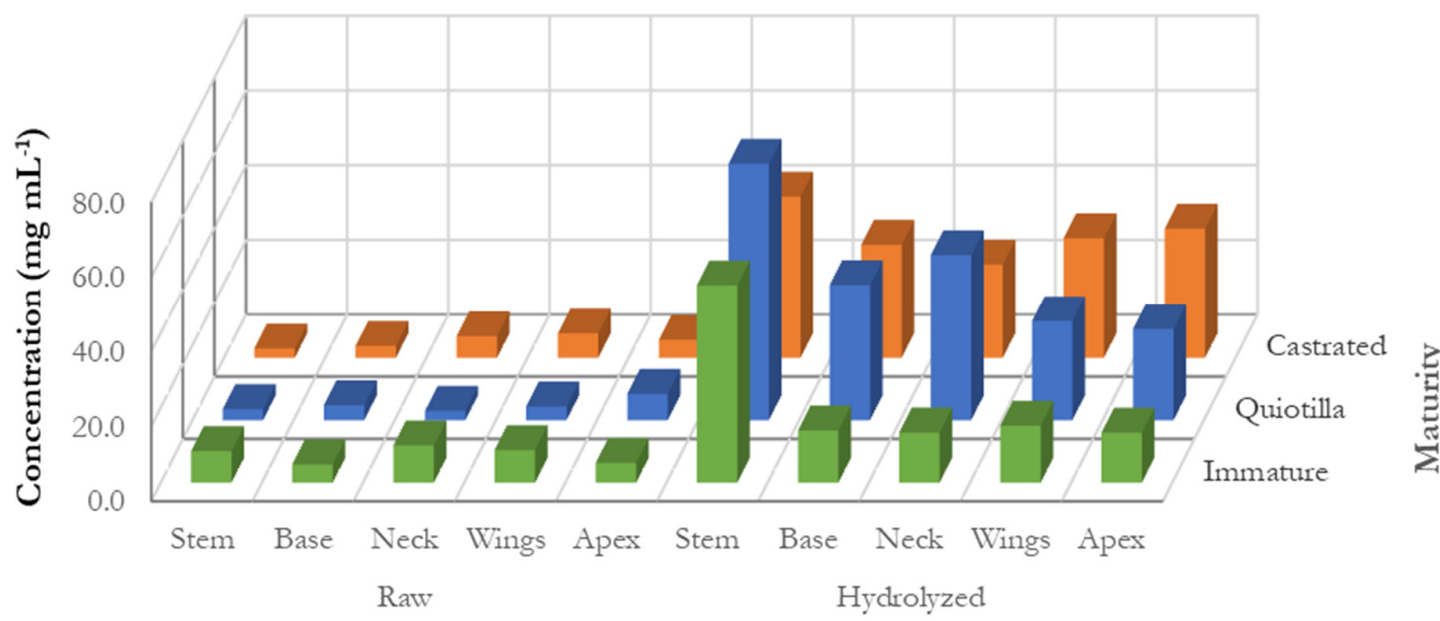

Plant section and treatment

Figure 3. Fructose concentration in raw and hydrolysed juices obtained from the stem and leaf (base, neck, wings and apex) of maguey (Agave salmiana) in three different maturity stages

\section{Glucose}

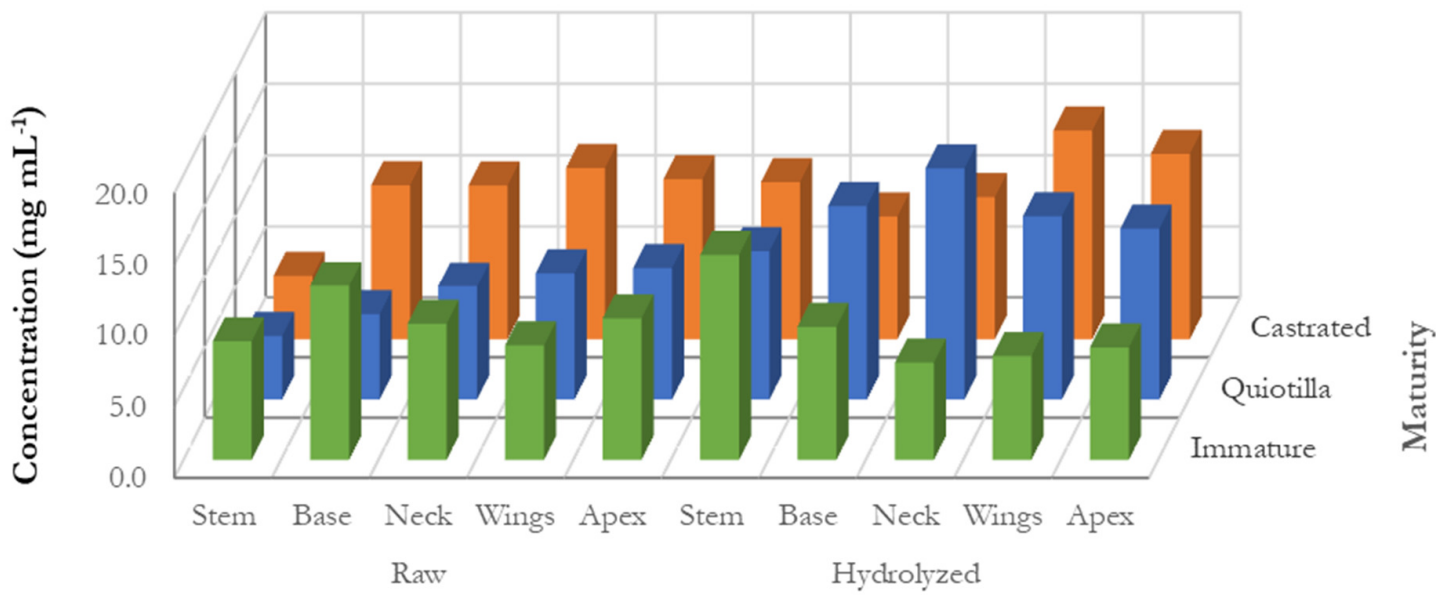

Plant section and treatment

Figure 4. Glucose concentration in raw and hydrolyzed juices obtained from stem and leaf (base, neck, wings and apex) of maguey (Agave salmiana) in three different maturity stages

Sucrose. The hydrolysis treatment had a statistically positive effect since it increased the sucrose concentration in the stem juices of the plant in its three maturity stages, which present the highest sucrose concentration. The highest concentration of this sugar was observed in hydrolysed juices from quiotilla plants stems $\left(8.90 \mathrm{mg} \mathrm{ml}^{-1}\right.$ ) (Figure 5). As mentioned above, during the use of this plant by the mezcal industry, only the stem and leaf base from castrated plants are used; however, it is recommended to reconsider (under these same conditions) the use of the rest of the leaf since the sucrose concentration is statistically similar to that of its stem $\left(4.79 \mathrm{mg} \mathrm{ml}^{-1}\right)$. 


\section{Sucrose}

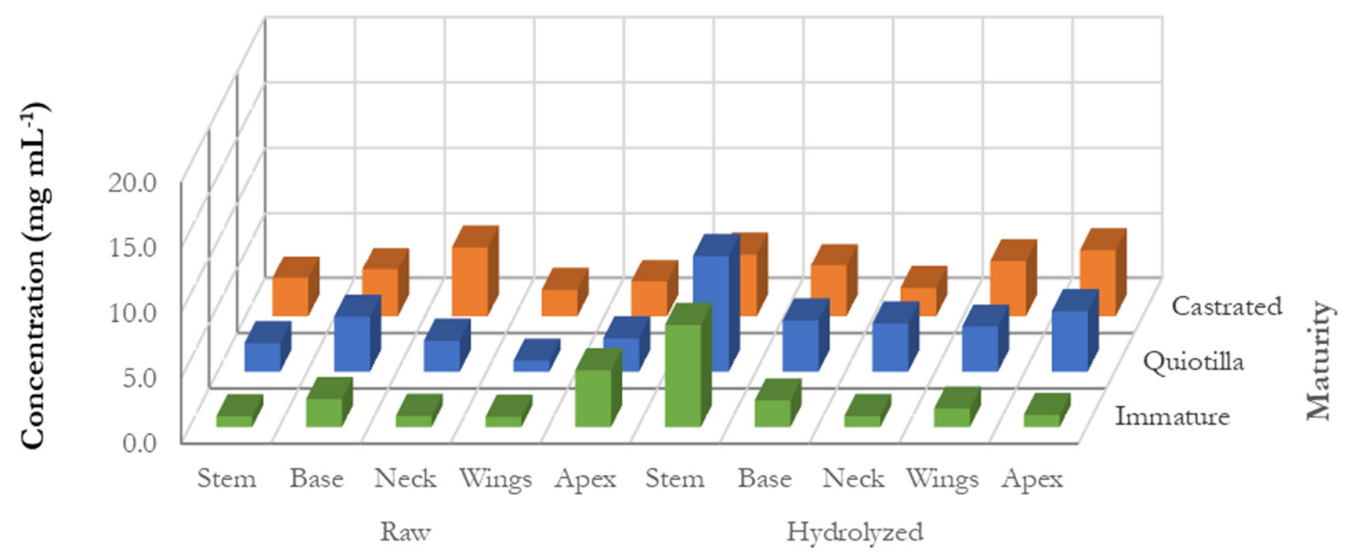

Plant section and treatment

Figure 5. Sucrose concentration in raw and hydrolyzed juices obtained from stem and leaf (base, neck, wings and apex) of maguey (Agave salmiana) in three different maturity stages

The state of maturity did not significantly affect the concentration of sucrose in each part of the plant.

Xylose. The concentration of xylose was higher in immature and quiotillas plants raw juices obtained from the wings and the apex, statistically similar between them, with a concentration range between 12.01 and $13.87 \mathrm{mg} \mathrm{ml}^{-1}$ (Figure 6), and its concentration decreases as the plant matures. In the castrated plants there was no significant difference between all the treatments.

Maltose. The highest maltose concentration with a statistically significant difference was found in raw leaf base juices from castrated plants $\left(11.36 \mathrm{mg} \mathrm{ml}^{-1}\right)$ followed by those from quiotilla plants $\left(9.54 \mathrm{mg} \mathrm{ml}^{-1}\right)$ (Figure 7). There was a significant difference between heat treatment in leaf base juices from the three stages of maturity.

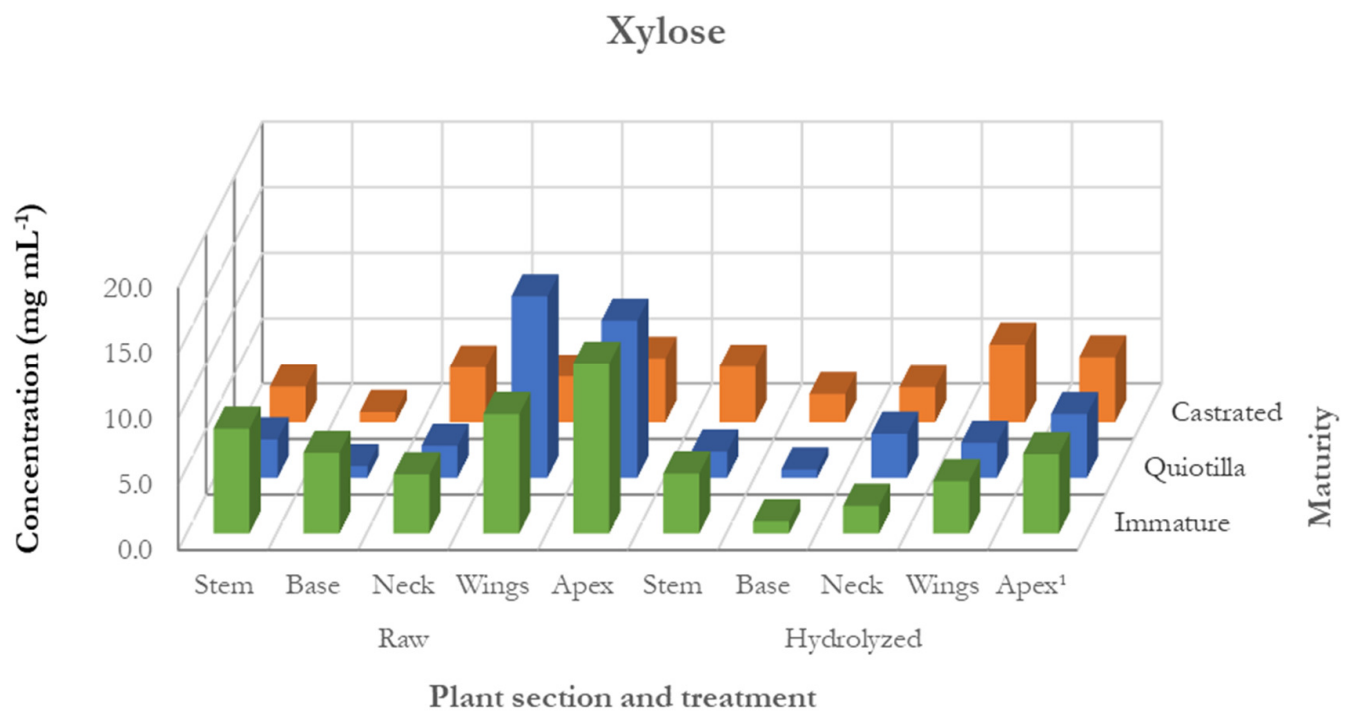

Figure 6. Xylose concentration in raw and hydrolyzed juices obtained from stem and leaf (base, neck, wings and apex) of maguey (Agave salmiana) in three different maturity stages 


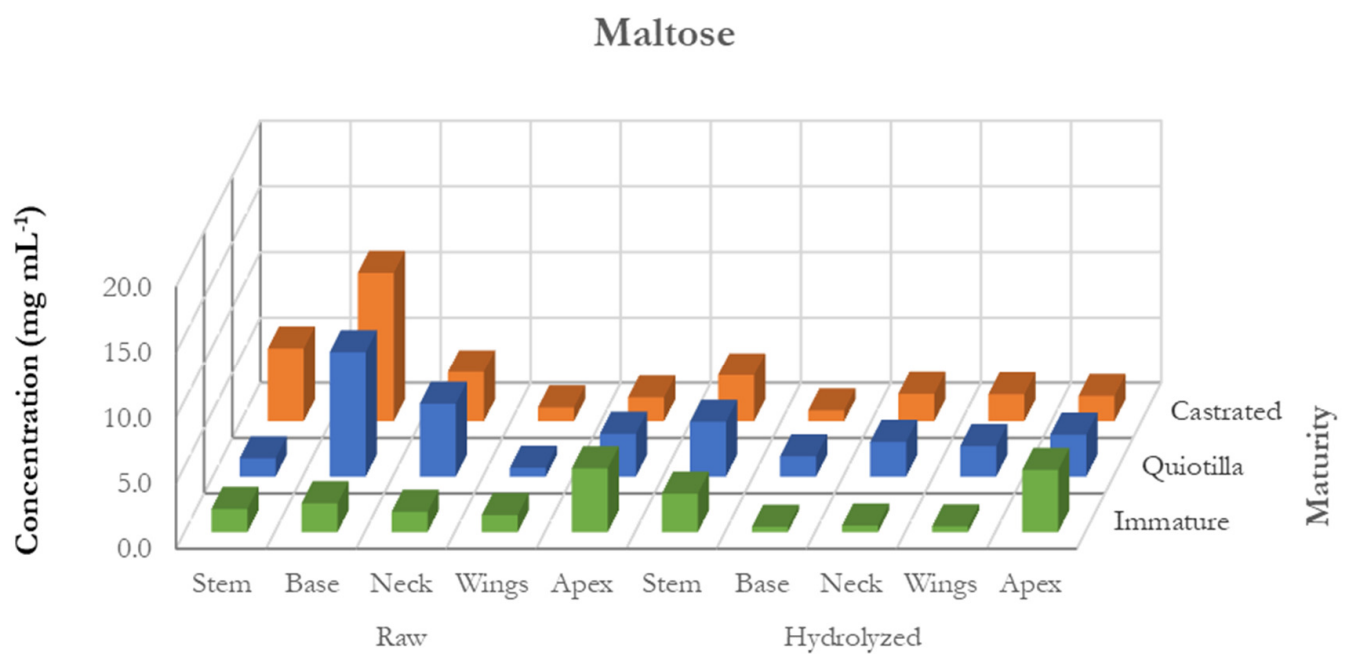

Plant section and treatment

Figure 7. Maltose concentration in raw and hydrolysed juices obtained from stem and leaf (base, neck, wings and apex) of maguey (Agave salmiana) in three different maturity stages

\section{Discussion}

The carbohydrates identified in this study coincide with those found in other species of the Agavegenus such as A. vera-cruz (Wang and Nobel, 1998; López and Mancilla, 2002; López et al., 2003). The presence of these carbohydrates has been confirmed in Agave salmiana by other chromatographic techniques (MichelCuello et al., 2015).

Fructose. According to the results, there is evidence that confirms the increase in the fructose concentration in hydrolysed maguey juices, which are detached from the fructans structure when subjected to a hydrolysis process by fructo-hexohydrolase (FEH) that acts on fructose-bonds releasing fructose between 10 and 60 fructose molecules depending on its structure and bond type, the increase in fructose concentration is more evident in the juices from the plant stem, since it is at this point where they are located and stored fructans as a usable energy source in drought periods or when their metabolism requires a greater energy supply for their growth and reproduction (Wang and Nobel, 1998; López and Mancilla, 2002; Ritsema and Smeekens, 2003; Mancilla and López, 2006; Moreno et al., 2014; Chávez et al., 2016; Acosta et al., 2018; García et al., 2020). It is extremely important to note that the concentration of fructose in hydrolyzed juices from castrated plants does not present a statistically significant difference depending on the plant section. In fact, the fructose concentration of hydrolysed juices in castrated plants obtained from wings and apex is higher than the concentration in leaf base juices (used in the industrial processes of mezcal) subjected to the same treatment. These results must be considered during industrial processes to increase the yield in the mezcal production. Based on these results, it is recommended to consider the plant discarded parts (neck, wings, and leaf apex) due to their glucose and fructose content and their use as fermentable sugars to obtain mezcal (De los Rios and Rutiaga, 2015). The fructose concentration presented statistical significance supported by the interactions of the plant section with treatment and the maturity state with treatment, the reason for this is due to the concentration gradient of fructans that were formed from the polymerization of fructose molecules that were move towards the stem to be stored as energy reserve, which when hydrolysed release fructose (Montañez et al., 2014).

Glucose. The hydrolysis process had a positive effect on the increase in glucose concentration in quiotilla and castrated plants juices, and the highest concentration of this sugar with a statistically significant difference 
was observed in juices obtained from the neck of quiotilla plants and in juices of castrated plant wings. This phenomenon can be explained by the presence of fructans that, when hydrolysed, also release a glucose unit per molecule, for this reason the increase in glucose concentration when cooking the juices from the stem and the base of the leaf. The interactions effect between the treatments was determined, in such a way that the section of the plant interacting with the hydrolysis had significant effect on glucose concentration, probably caused by the release of molecules of this carbohydrate from the fructans hydrolysis, sucrose or even small maltose concentrations (López et al., 2003; Michel-Cuello et al., 2012; Moreno et al., 2017).

Sucrose. The sucrose concentration is limited by the plant metabolism, which hydrolyses this sugar using the enzyme invertase or sucrose-synthase to release glucose and fructose for immediate energy, to be used during respiration, or to polymerize it to form fructans as energy reserve in the stem. Similarly, sucrose is considered the sugar transporter and is found in a dynamic state in the plant (Srinivasan and Bathia, 1953; Echeverría, 1990; Goldschmidt and Huber, 1992; Davies and Robinson, 1996).

Xylose. The statistically significant differences in terms of the higher xylose concentration in juices from wings and apex of immature and quiotillas plants depend of the plant metabolism, since this carbohydrate performs different functions in the plant, mainly as energy of cellular metabolism and for biomass generation; xylose is found associated with polysaccharides such as hemicellulose and with xyloglucan in the primary cell wall or as xylan constituents giving structure to the cell wall (Hayashi et al., 1998; Saucedo et al., 2010). The results indicate that the plant castration has a negative effect in xylose formation and storage in the plant. According to the results, the xylose concentration in maguey juices can be considered for industrial applications in ethanol production, sweeteners and as a xylitol source (Harner et al., 2015; Ortiz et al., 2017).

Maltose. The heat treatment generally decreases the maltose concentration regardless of the maturity stage or the plant section, this is due to the release two glucose molecules during the hydrolysis of each maltose molecule. The presence of maltose in maguey comes from the transitory starch, hydrolysed by $\beta$-amylase in the leaves at night, which substitutes the energy supply provided by the monosaccharides produced in photosynthesis during the day (Lu et al., 2005; Weise et al., 2005; Mellado and López, 2015).

\section{Conclusions}

The agave is a natural resource of regional origin for the mezcal production. It is subject not only to climatic variations such as droughts, pests, soil fertility and socio-economic and cultural factors of the producers, but also to fluctuations in the market and the global competition from traditional beverages (such as whiskey, cognac, brandy, vodka and even tequila, etc.) and the preference of final consumers. Therefore, it is necessary to incorporate innovations in production systems and quality control to ensure the competitiveness and sustainability of this beverage in the world market. In this sense, the high-performance liquid chromatography (HPLC) is a reliable technique for the identification and quantification of carbohydrates in maguey juice samples.

The results obtained in this research work indicate that in addition to fructose, glucose and sucrose, maltose and xylose were also identified, the latter carbohydrate has potential industrial application for the production of xylitol and as a sweetener. In fact, differences in the carbohydrate concentrations depending from the studied factors, such as part of the plant, state of maturity and raw or hydrolysed juices, were observed.

Based on the analysis results of the fructose concentration in hydrolysed juices, it is strongly recommended to consider the industrial use of plants in quiotilla maturity state, including the stem up to its neck, whose concentration is even higher than that presented in its base. In the case of castrated plants, the fructose concentration in the four sections of the leaf is statistically similar to the stem, so in this case it is advisable to consider alternative processes for the use of the whole plant. However, it is possible that the presence of other compounds in the maguey, such as waxes and saponins when decomposed by hydrolysis, either thermal or biological, could affect the efficiency of the process and the organoleptic characteristics of the final product. 
These treatments should be considered for a better use of the sugars contained in the maguey by the mezcal industry, which will collaterally reduce the impact of the maguey exploitation.

\section{Authors' Contributions}

Conceptualization: CMC and CLP; Methodology: CMC and NAR; Investigation: CMC, NAR and JFCG; Analysis of results: CMC, NAR and CLP; Writing - review and editing: CMC and NAR; All authors read and approved the final manuscript.

\section{Acknowledgements}

This study was supported by Middle Zone Multidisciplinary Academic Unit of Autonomous University of San Luis Potosí, through financial support for CAEF \# 253 Education and Engineering, and Faculty of Biological and Agricultural Sciences of University of Veracruz.

\section{Conflict of Interests}

The authors declare that there are no conflicts of interest related to this article.

\section{References}

Acosta DL, Alamilla BL, Calderón DG, Jiménez AAR, Gutiérrez LGF, Azuara NE (2018). Determination of total and incipient solubilization point of fructans extracted of $A$. tequilana weber var. azul. Revista Mexicana de Ingeniería Química 17:379-388. https://doi.org/10.24275/uam/izt/dcbi/revmexingquim/2018v17n1/Acosta

Aguirre RJR, Charcas H, Flores JL (2001). El maguey mezcalero potosino [The maguey mezcalero potosino]. Autonomous University of San Luis Potosí and Potosino Council of Science and Technology: San Luis Potosí.

Chávez RA, Farías CVS, Luna SG, Chávez RAM, Ortíz BRI, Andrade GI (2016). Quality attributes and particles deposition of spray dried fructans of blue Agave juice. Revista Mexicana de Ingeniería Química 15:493-502. http://rmiq.org/ojs311/index.php/rmiq/article/view/1159

Chinnici F, Spinabelli U, Amati A (2002). Simultaneous determination of organic acids, sugars, and alcohols in must a wine by an improved ion-exclusion HPLC method. Journal of Liquid Chromatography \& Related Technologies 25(16):2551-2560. https://doi.org/10.1081/JLC-120014274

Davies C, Robinson SP (1996). Sugar accumulation in grape berries (cloning of two putative vacuolar invertase cDNAs and their expression in grapevine tissues). Plant Physiology 111:175-273. https://doi.org/10.1104/pp.111.1.275

De los Rios DGC, Rutiaga QOM (2015). Improving Agave duranguensis must for enhanced fermentation. C/N ratio effects on mezcal composition and sensory properties. Revista Mexicana de Ingeniería Química 14:363-371. http://rmiq.org/oj3311/index.php/rmiq/article/view/1225

Echeverria E (1990). Developmental transition from enzymatic to acid hydrolysis of sucrose in acid limes (Citrus aurantifolia). Plant Physiology 92:168-171. https://doi.org/10.1104/pp.92.1.168

Esparza IEL, Violante GJ, Monks S, Cadena IJ, Araujo AC, Rössel KE (2015). Los agaves mezcaleros del altiplano Potosino y Zacatecano. In: Pulido FG, Monks S, López HM (Eds). Estudios en Biodiversidad Vol I, [The mezcal agaves of the Potosino and Zacatecano highlands. In Pulido FG, Monks S, López HM (Eds). Biodiversity Studies Vol I] Zea Book. Lincoln, https://www.researchgate.net/publication/286463988_Los_agaves_mezcaleros_del_altiplano_Potosino_y_Z acatecano 
García GR, Gradilla HMS, Ortiz BRI, García RRA, González AM (2020). Assessment of intermediate- and long- chains Agave fructan fermentation on the growth of intestinal bacteria cultured in a gastrointestinal tract simulator. Revista Mexicana de Ingeniería Química 19:827-838. https://doi.org/10.24275/rmiq/Bio842

García ME, Romero MA, Nobel PS (2010). Highlights for Agave productivity. GCB Bioenergy 3:1. https://doi.org/10.1111/j.1757-1707.2010.01078.x

Goldschmidt EE, Huber SC (1992). Regulation of photosynthesis by end - product accumulation in leaves of plants storing starch, sucrose, and hexose sugars. Plant Physiology 99:1443-1448. https://doi.org/10.1104/pp.99.4.1443

Goldstein G, Ortega JK, Nerd A, Nobel PS (1991). Diel patterns of water potential components for the crassulacean acid metabolism plant Opuntia ficus-indica when well-watered on droughted. Plant Physiology 95:274-280. https://doi.org/10.1104/pp.95.1.274

Gómez GAV, Valdez VI, Caballero CM, Chiñas CF, Alavéz RR, Montes BJL (2019). Co-digestion of Agave angustifolia haw bagasse and vinasses for biogasproduction from mezcal industry. Revista Mexicana de Ingeniería Química 18:1073-1083. https://doi.org/10.24275/uam/izt/dcbi/revmexingquim/2019v18n3/Gomez

Harner NK, Wen X, Bajwa PK, Austin GD, Ho CY, Habash MB, ... Lee H (2015). Genetic improvement of native xylose-fermenting yeasts for ethanol production. Journal of Industrial Microbiology and Biotechnology 42:120. https://doi.org/10.1007/s10295-014-1535-Z

Hayashi T, Koyama T, Matsuda K (1998). Formation of UDP-xylose and xyloglucan in soybean Golgi membranes. Plant Physiology 87:341-345. https://doi.org/10.1104/pp.87.2.341

Hofer K, Jenewein D (1999). Enzymatic determination of inulin in food and dietary supplements. European Food Research and Technology 209:423-427. https://doi.org/10.1007/s002170050520

Jaramillo L, Pazutti LB, de Aguiar PF, Ferreira LVS, Sérvulo EC (2020). Determination of metabolites involved in fermentative succinic acid production from glucose, glycerol and crude glycerin by HPLC methodology. Revista Mexicana de Ingeniería Química 19:653-667. https://doi.org/10.24275/rmiq/Bio747

Lara HC, Grajales LA, Ruiz CMA, Ventura CC, Gutiérrez MFA, Ruiz VVN, Abud AM (2017). Agave americana honey fermentation by Kluyveromyces marxianus strain for "comiteco" production, a spirit from Mexican southeast. $\begin{array}{lllll}\text { Revista Mexicana } & \text { de } & \text { Ingeniería }\end{array}$ http://rmiq.org/oj3311/index.php/rmiq/article/view/932

Lee HS, Coates GA (2000). Quantitative study of free sugars and myo-inositol in citrus juices by HPLC and a literature compilation. Journal of Liquid Chromatography \& Related Technologies 23(14):2123-2141. https://doi.org/10.1081/JLC-100100476

López MG, Mancilla MNA (2002). Generation of maillard compounds from inulin during the thermal processing of Agave tequilana Weber var. azul. Journal of Agricultural and Food Chemistry 50:806-812. https://doi.org/10.1021/jf0110295

López MG, Mancilla MNA, Mendoza DG (2003). Molecular structures of fructans from Agave tequilana Weber var. azul. Journal of Agricultural and Food Chemistry 51:7835-7840. https://doi.org/10.1021/jf030383V

Lu Y, Gehan JP, Sharkey TD (2005). Daylength and cicardian effects on starch degradation and maltose metabolism. Plant Physiology 138:2280-2291. https://doi.org/10.1104/pp.105.061903

Mancilla MNA, López MG (2006). Water-soluble carbohydrates and fructan structure patterns from Agave and Dasylirion species. Journal of Agricultural and Food Chemistry 54:7832-7839. https://doi.org/10.1021/jf060354V

Mellado ME, López MG (2015). Identification, classification, and discrimination of Agave syrups from natural sweeteners by infrared spectroscopy and HPAEC-PAD. Food Chemistry 167:349-357. http://dx.doi.org/10.1016/j.foodchem.2014.06.111

Michel-Cuello C (2004). Mejoramiento de la eficiencia en la molienda en el proceso de elaboración de mezcal potosino [Improvement of milling efficiency in the potosino mezcal production process]. Bachelor's thesis. Autonomous University of San Luis Potosí.

Michel-Cuello C, Juárez FBI, Aguirre RJR, Pinos RJM (2008). Quantitative characterization of nonstructural carbohydrates of mezcal Agave (Agave salmiana Otto ex Salm-Dick). Journal of Agricultural and Food Chemistry 56:5753-5757. https://doi.org/10.1021/jf800158p

Michel-Cuello C, Ortíz CI, Moreno VL, Grajales LA, Moscosa SM, Bonnin J, ... Ruiz CMA (2012). Study of enzymatic hydrolysis of fructans from Agave salmiana characterization and kinetic assessment. The Scientific World Journal. https://doi.org/10.1100/2012/863432 
Michel-Cuello C, Gallegos FG, Maldonado CE, Aguilar-Rivera N (2015). Effect of temperature and pH environment on the hydrolysis of maguey fructans to obtain fructose syrup. Revista Mexicana de Ingeniería Química 14:615-622. http://www.rmiq.org/iqfvp/Pdfs/Vol.\%2014,\%20No.\%203/Alim5/RMIQTemplate.pdf

Montañez SJL, Venegas GJ, Ceja TL, Castellanos PN, Yañez FJ (2014). Fractional extraction of the fructans contained in the Agave tequilana weber blue head based on their average degree of polymerization. Advances in Bioresearch. 5:107-113. http://www.soeagra.com/abr/abrsept_2014/19.pdf

Mora MI, Marioli JM (2001). Honey carbohydrate analysis by HPLC, with electrochemical detection, using a Ni-Cr alloy electrode. Journal of Liquid Chromatography \& Related Technologies 24(5):711-720. https://doi.org/10.1081/JLC-100103405

Moreno VL, Garcia HMH, Delgado PRE, Corral FNE, Cortez EN, Ruiz CMA, Portales PDP (2014). In vitro assessment of Agave fructans (Agave salmiana) as prebiotics and immune system activators. International Journal of Biological Macromolecules 63:181-187. https://doi.org/10.1016/j.ijbiomac.2013.10.039.

Moreno VL, Bostyn S, Flores MJL, Camacho RR (2017). Size-exclusion chromatography (HPLC-SEC) technique optimization by simplex method to estimate molecular weight distribution of Agave fructans. Food Chemistry 237:833-540. https://doi.org/10.1016/j.foodchem.2017.06.020

Ortiz MOH, Morales MTK, Ríos GLJ (2017). Bioethanol production from Agave lechuguilla biomass pretreated by autohydrolysis. Revista Mexicana de Ingeniería Química 16:467-476. http://rmiq.org/iqfvp/Pdfs/Vol.\%2016,\%20No.\%202/Alim7/RMIQTemplate.pdf

Ritsema T, Smeekens S (2003). Engineering fructan metabolism in plants. Plant Physiology 160:811-820. https://doi.org/10.1078/0176-1617-01029

Romero LMR, Osorio DP, Flores MA, Robledo N, Mora ER (2015). Chemical composition, antioxidant capacity and prebiotic effect of aguamiel (Agave atrovirens) during in vitro fermentation. Revista Mexicana de Ingeniería Química. 14:281-292. http://rmiq.org/oj3311/index.php/rmiq/article/view/1202

Saucedo LJ, Castro MAJ, Rico JL, Campos GJ (2010). Optimization of acid hydrolysis of bagasse from Agave tequilana Weber. Revista Mexicana de Ingeniería Química 91-97. http://www.redalyc.org/articulo.oa?id=62016243011

Solís GA, Rivas GP, Escamilla AC, Rico MR, Bravo SMG, Botello AJE (2017). Methanol production kinetics during Agave cooking for mezcal industry. Revista Mexicana de Ingeniería Química 16:827-834. http://rmiq.org/ojs311/index.php/rmiq/article/view/944

Srinivasan M, Bathia IS (1953). The carbohydrates of Agave vera cruz Mill. Biochemical Journal 55:286-289. https://doi.org/10.1042/bj0550286

Wang N, Nobel P (1998). Phloem transport of fructans in the crassulacean acid metabolism species Agave deserti. Plant Physiology 116:709-714. https://doi.org/10.1104/pp.116.2.709

Weise SE, Kim KS, Stewart RP, Sharkey TD (2005). $\beta$ - maltose is the metabolically active anomer of maltose during transitory starch degradation. Plant Physiology 137:756-761. https://doi.org/10.1104/pp.104.055996

Zhang H, Nobel PS (1996). Photosynthesis and carbohydrate partitioning for the $\mathrm{C}_{3}$ desert shrub Encelia farinosa under current and doubled $\mathrm{CO}_{2}$ concentrations. Plant Physiology 110:1361-1366. https://doi.org/10.1104/pp.110.4.1361

Zúñiga EL, Rosales RE, Yáñez MML, Jaques HC (2018). Características y productividad de una planta MAC, Agave tequilana desarrollada con fertigación en Tamaulipas, México [Characteristics and productivity of a MAC plant, Agave tequilana developed with fertigation in Tamaulipas, Mexico]. Revista Mexicana de Ciencias Agrícolas 9:553-564. https://doi.org/10.29312/remexca.v9i3.1214 
Michel-Cuello C et al. (2021). Not Bot Horti Agrobo 49(1):12154

OPEN ACCESS

(c) (2)

The journal offers free, immediate, and unrestricted access to peer-reviewed research and scholarly work. Users are allowed to read, download, copy, distribute, print, search, or link to the full texts of the articles, or use them for any other lawful purpose, without asking prior permission from the publisher or the author.

License - Articles published in Notulae Botanicae Horti Agrobotanici Cluj-Napoca are Open-Access, distributed under the terms and conditions of the Creative Commons Attribution (CC BY 4.0) License. (C) Articles by the authors; UASVM, Cluj-Napoca, Romania. The journal allows the author(s) to hold the copyright/to retain publishing rights without restriction. 